\title{
Distinct single cell signal transduction signatures in leukocyte subsets stimulated with khat extract, amphetamine-like cathinone, cathine or norephedrine
}

Therese Bredholt ${ }^{1 \dagger}$, Elisabeth Ersvær ${ }^{1,2+}$, Bjarte Skoe Erikstein ${ }^{1}$, André Sulen ${ }^{1}$, Håkon Reikvam ${ }^{1,3}$, Hans Jørgen Aarstad ${ }^{4,5}$, Anne Christine Johannessen ${ }^{5,6}$, Olav Karsten Vintermyr ${ }^{5,6}$, Øystein Bruserud ${ }^{1,3}$ and Bjørn Tore Gjertsen ${ }^{1,3^{*}}$

\begin{abstract}
Background: Amphetamine and amphetamine derivatives are suggested to induce an immunosuppressive effect. However, knowledge of how amphetamines modulate intracellular signaling pathways in cells of the immune system is limited. We have studied phosphorylation of signal transduction proteins (Akt, CREB, ERK1/2, NF-KB, c-Cbl, STAT1/3/5/6) and stress sensors (p38 MAPK, p53) in human leukocyte subsets following in vitro treatment with the natural amphetamine cathinone, the cathinone derivatives cathine and norephedrine, in comparison with a defined extract of the psychostimulating herb khat (Catha edulis Forsk.). Intracellular protein modifications in single cells were studied using immunostaining and flow cytometry, cell viability was determined by Annexin V-FITC/Propidium lodide staining, and T-lymphocyte proliferation was measured by ${ }^{3} \mathrm{H}$-thymidine incorporation.

Results: Cathinone, cathine and norephedrine generally reduced post-translational modifications of intracellular signal transducers in T-lymphocytes, B-lymphocytes, natural killer cells and monocytes, most prominently affecting c-Cbl (pTyr700), ERK1/2 (p-Thr202/p-Tyr204), p38 MAPK (p-Thr180/p-Tyr182) and p53 (both total p53 protein and pSer15). In contrast, the botanical khat-extract induced protein phosphorylation of STAT1 (p-Tyr701), STAT6 ( $p$ Tyr641), c-Cbl (pTyr700), ERK1/2 (p-Thr202/p-Tyr204), NF-kB (p-Ser529), Akt (p-Ser473), p38 MAPK (p-Thr180/pTyr182), p53 (Ser15) as well as total p53 protein. Cathinone, cathine and norephedrine resulted in unique signaling profiles, with B-lymphocytes and natural killer cells more responsive compared to T-lymphocytes and monocytes. Treatment with norephedrine resulted in significantly increased T-lymphocyte proliferation, whereas khat-extract reduced proliferation and induced cell death.

(Continued on next page)
\end{abstract}

\footnotetext{
*Correspondence: bjorn.gjertsen@med.uib.no

${ }^{\dagger}$ Equal contributors

${ }^{1}$ Department of Clinical Science, University of Bergen, Bergen, Norway

${ }^{3}$ Department of Internal Medicine, Haukeland University Hospital, Bergen,

Norway

Full list of author information is available at the end of the article
} 


\section{(Continued from previous page)}

Conclusions: Single-cell signal transduction analyses of leukocytes distinctively discriminated between stimulation with cathinone and the structurally similar derivatives cathine and norephedrine. Cathinone, cathine and norephedrine reduced phosphorylation of c-Cbl, ERK1/2, p38 MAPK and p53(Ser15), and norephedrine induced Tlymphocyte proliferation. Khat-extract induced protein phosphorylation of signal transducers, p38 MAPK and p53, followed by reduced cell proliferation and cell death. This study suggests that protein modification-specific singlecell analysis of immune cells could unravel pharmacologic effects of amphetamines and amphetamine-like agents, and further could represent a valuable tool in elucidation of mechanism(s) of action of complex botanical extracts.

Keywords: Signal transduction, Leukocytes, Single-cell modification-specific flow cytometry, Natural amphetamine, Cathinone, Khat-extract

\section{Background}

The herbal drug khat (Catha edulis Forsk.) is chewed for its psychostimulating effects by millions of people [1,2]. The alkaloid cathinone represents its main psychoactive compound, with a structure and pharmacological profile similar to the synthetic drug amphetamine [3]. Cathinone represents a labile precursor for cathine and norephedrine [3], being metabolized primarily to norephedrine in vivo [4]. In addition to cathinone and its derivates, khat contains other bioactive constituents, including tannins, ascorbic acid, the phenylalkylamine meruchatine [5], catheduline alkaloids [6], flavonoids and triterpenoids [3,7].

During khat chewing, cathinone, cathine and norephedrine are extracted into saliva, and the oral buccal mucosa plays a major role in absorption [8]. Like amphetamine, cathinone induces release of dopamine, serotonin (5-hydroxytryptamine, 5-HT) and noradrenaline from presynaptic neuronal terminals, and has further been suggested to inhibit neurotransmitter reuptake [3]. Cathinone, cathine and norephedrine have been shown to act as substrates at the noradrenaline and dopamine transporters, to bind $\alpha_{2}$-adrenergic receptors $[9,10]$, and cathinone has in addition been reported to bind 5-HT receptors $[10,11]$. The $\beta_{1}$-adrenergic receptor was suggested to mediate khat-induced increase in systolic blood pressure and pulse rate [12], whereas the $\alpha_{1}$-adrenergic receptor has been implicated in bladder dysfunction following khat chewing [13].

Leukocytes express transporters and receptors for dopamine and serotonin, and several types of immune cells store these neurotransmitters (reviewed in $[14,15]$ ). It has further been suggested that lymphocytes are capable of producing dopamine [16,17]. Leukocytes are known to express adrenergic receptors, and expression of the noradrenaline transporter has also been reported [18]. Various drugs that influence neurotransmitter transport, including anti-depressants and amphetamines, have demonstrated immunosuppressive effects in vivo (reviewed in $[14,19])$. Several studies have suggested that at least part of the immunosuppression could be due to direct impact of such pharmacological substrates on immune cells. For instance, House et al. reported that amphetamine could suppress B-lymphocyte proliferation and IL-2 secretion from T-lymphocytes in vitro [20]. Amphetamine was further seen to reduce zymosan-induced phagocytosis both in vitro and in vivo [21].

Intracellular signal transduction proteins and cell stress sensors have been linked to activation of adrenergic, dopaminergic and serotonergic receptors, which represent G-protein coupled receptors. The $\beta$-adrenergic/G stimulatory/protein kinase A pathway was reported to induce phosphorylation of mitogen-activated protein kinase (MAPK) p38 in activated B-lymphocytes [22] and in T-lineage cells [23]. $5-\mathrm{HT}_{7}$ receptor stimulation on naïve T-lymphocytes has been suggested to induce activation of extra-cellular regulated kinase 1/2 (ERK1/2) [24]. Further, stimulation of dopaminergic D2-like receptors was reported to reduce phosphorylation of cyclic AMP response element binding (CREB) protein in $\mathrm{T}$ lymphocytes [25].

In this study we exposed peripheral blood leukocytes in vitro to cathinone, cathine, norephedrine, and to physiological relevant concentrations of khat-extract, and investigated the impact on selected signaling and stress sensor proteins. The distinct signatures of protein modifications detected in the leukocyte subsets indicate cellular effects and mechanism(s) of action of the khatderived alkaloids, and further demonstrate that the cellular signaling response diverge from treatment with a complex botanical khat-extract.

\section{Results}

Peripheral blood mononuclear cells (PBMCs) from healthy donors $(n=6)$ were treated with khat-extract $\left(10^{-3}\right.$ and $3.16 \times 10^{-4}$ dilutions), cathinone, cathine and norephedrine $\left(10^{-4} \mathrm{M}\right.$ concentrations) for 4,10 and 15 minutes, in vitro. Based on cathinone, cathine and norephedrine concentrations in the khat-extract, the experimental dilutions should be comparative to local concentrations of khat constituents in vivo during khat chewing (Table 1) [26]. The impact on signal transduction proteins and stress sensors in T-lymphocytes, B- 
Table 1 Cathinone, cathine and norephedrine concentrations in the khat-extract stock solution, and in experimental cell cultures

\begin{tabular}{|c|c|c|c|c|c|c|}
\hline & \multicolumn{2}{|l|}{ Cathinone } & \multicolumn{2}{|l|}{ Cathine } & \multicolumn{2}{|c|}{ Norephedrine } \\
\hline & \multicolumn{2}{|l|}{ Mw 150.1} & \multicolumn{2}{|l|}{ Mw 152.1} & \multicolumn{2}{|l|}{ Mw 152.1} \\
\hline & $\mathrm{mg} \mathrm{ml}^{-1}$ & $\mathbf{M}$ & $\mathrm{mg} \mathrm{ml}^{-1}$ & M & $\mathrm{mg} \mathrm{ml}^{-1}$ & M \\
\hline khat-extract stock solution & 2.5 & $1.7 \times 10^{-2}$ & 3.0 & $2.0 \times 10^{-2}$ & 0.3 & $2.0 \times 10^{-3}$ \\
\hline $10^{-3}$ dilution & $2.5 \times 10^{-3}$ & $1.7 \times 10^{-5}$ & $3 \times 10^{-3}$ & $2.0 \times 10^{-5}$ & $3 \times 10^{-4}$ & $2.0 \times 10^{-6}$ \\
\hline $3.16 \times 10^{-4}$ dilution & $7.9 \times 10^{-4}$ & $5.4 \times 10^{-6}$ & $9.5 \times 10^{-4}$ & $6.3 \times 10^{-6}$ & $9.5 \times 10^{-5}$ & $6.3 \times 10^{-7}$ \\
\hline
\end{tabular}

The stock solution concentrations were determined based on HPLC-MS-MS analyses [30].

lymphocytes, natural killer (NK) cells and monocytes was assessed using modification-specific antibodies and flow cytometric analyses (Figure 1A).

Fold change values based on median fluorescence intensity (MFI) measurements were used as basis for data analyses, and signal transduction signatures for the leukocyte subsets are displayed as heatmaps of statistical significant changes (Figure 1B, 2A, 3A, 4A), and as cluster analyses (Figure 1C, 2B, 3B, 4B). The levels of phosphorylated ( $\mathrm{p}$ ) signal transducer and activator of transcription (STAT) 5, p-CREB, and p53 acetylated (ac)-Lysine (Lys)382 were not significantly altered by any stimulus (Additional file 1: Table S1) and were excluded from the heatmaps (Figure 1B, 2A, 3A, 4A) but included in the cluster analyses of signaling responses (Figure 1C, 2B, 3B, 4B). Cathinone did not induce significant signaling responses at the concentration and exposure times tested.

\section{Signal transduction in T-lymphocytes}

For T-lymphocytes (Figure 1B), treatment with the lowest khat-extract concentration induced p-STAT1, p-p38 MAPK, p-STAT6 and p-AKT; the highest khat-extract concentration induced p-c-Cbl, p-ERK1/2, p-p38 MAPK, p53 p-Serine (Ser)15 and total p53; cathine reduced pc-Cbl, p-ERK1/2, p-p38 MAPK, p53 p-Ser15 and total $\mathrm{p} 53$; the combination norephedrine/cathinone reduced p-c-Cbl and p53 p-Ser15. The time-points and p-values for these changes are listed in Additional file 1: Table S1.

The cluster analysis of signal transduction in $\mathrm{T}$ lymphocytes following 15 minutes of stimulation present significant and non-significant changes (Figure 1C). Khatextract generally increased protein phosphorylation, in contrast to cathinone, cathine and norephedrine, which reduced phosphorylation of several proteins. Cathinone and its derivatives clustered separately from khat-extract, indicating different pharmacological properties of the complex extract compared to the pure khat components.

\section{Signal transduction in B-lymphocytes}

For B-lymphocytes (Figure 2A), treatment with the lowest khat-extract concentration induced p-STAT1, p-p38 MAPK, p-STAT6, p-AKT and p53 p-Ser37; the highest concentration of khat-extract induced p-STAT1, p-c-Cbl, p-ERK1/2, p-STAT3, p-NF-kB, p-p38 MAPK, p53 pSer15 and total $\mathrm{p} 53$. In contrast, cathine reduced $\mathrm{p}$ c-Cbl, p-ERK1/2, p-p38 MAPK, p53 p-Ser15 and total $\mathrm{p} 53$; the combination norephedrine/cathinone reduced p53 p-Ser15. The time-points and p-values for these changes are listed in Additional file 1: Table S1.

The cluster analysis of signal transduction in Blymphocytes (15 minutes) displays significant and nonsignificant changes (Figure 2B). As in T-lymphocytes, khat-extract induced protein phosphorylation, whereas cathinone and its derivatives decreased phosphorylation levels. In particular, p-c-Cbl, p-ERK1/2, p-p38- MAPK and p53 p-Ser15 were prominently reduced, and these phosphorylation responses clustered together.

\section{Signal transduction in natural killer cells}

For NK cells (Figure 3A), treatment with the lowest khat-extract concentration induced p-STAT1, p-STAT3, $\mathrm{p}-\mathrm{NF}-\mathrm{kB}, \mathrm{p}-\mathrm{STAT} 6, \mathrm{p}-\mathrm{AKT}$ and total p53; the highest khat-extract concentration induced $\mathrm{p}-\mathrm{c}-\mathrm{Cbl}, \mathrm{p}-\mathrm{ERK} 1 / 2$, p-STAT3, p-NF-kB, p-p38 MAPK, p53 p-Ser15 and total p53; norephedrine induced p-STAT3; cathine reduced $\mathrm{p}$ c-Cbl, p-ERK1/2, p-p38 MAPK and p53 p-Ser15. The time-points and p-values for these changes are listed in Additional file 1: Table S1. The cluster analysis of signal transduction in NK cells (15 minutes) displays significant and non-significant changes (Figure 3B). In NK cells, cathinone and its derivatives both induced and decreased protein phosphorylation.

\section{Signal transduction in monocytes}

For monocytes (Figure 4A), treatment with the lowest khat-extract concentration induced p-STAT1, p-p38 MAPK, p-STAT6 and p-AKT; the highest khat-extract concentration induced p-c-Cbl, p-ERK1/2, p-p38 MAPK, p53 p-Ser15 and total p53; cathine reduced p-c-Cbl and p53 p-Ser15. The cluster analysis of signal transduction in monocytes (15 minutes) indicates significant and nonsignificant changes (Figure 4B). Cathinone and its derivatives gave a less pronounced reduction in phosphorylation levels in the monocyte subset. 

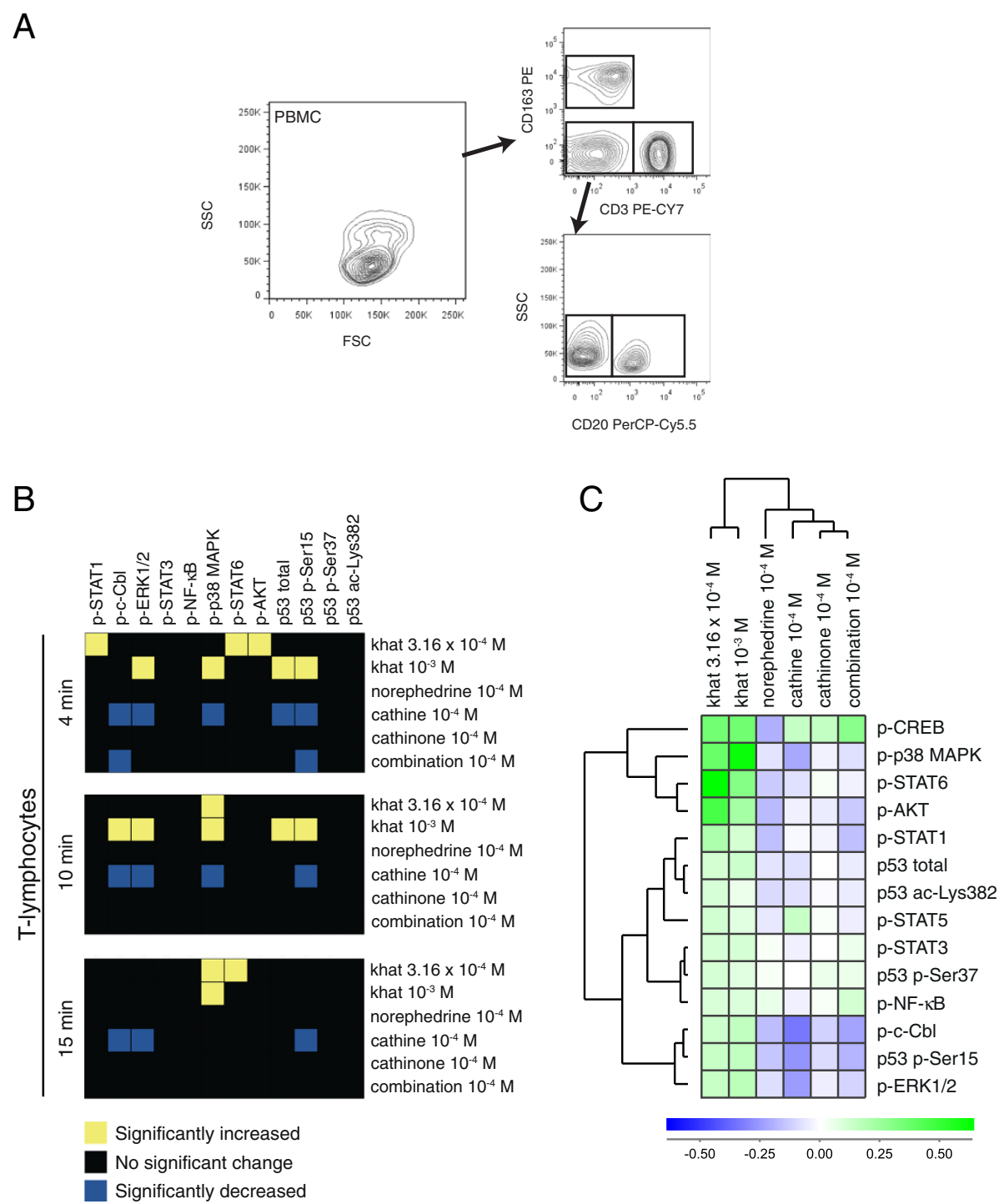

Figure 1 Gating strategies and signal transduction in T-lymphocytes. PBMCs $(n=6)$ were stimulated with khat-extract $\left(10^{-3}\right.$ and $3.16 \times 10^{-4}$ dilutions), cathinone, cathine, norephedrine $\left(10^{-4} \mathrm{M}\right)$ and a combination of cathinone and norephedrine (combination: $\left.2 \times 10^{-4} \mathrm{M}\right)$ for 4,10 and 15 minutes, in vitro. (A) The PBMCs were fixed, permeabilized, stained with antibodies against specific cell surface markers and modificationspecific antibodies and analyzed by flow cytometry. The PBMCs were identified as T-lymphocytes (CD3 $\left.{ }^{+} \mathrm{CD}_{20} \mathrm{CD}^{-} \mathrm{CB}^{-}\right), \mathrm{B}^{-l y m p h o c y t e s}\left(\mathrm{CD}^{-}\right.$ CD20 ${ }^{+}$CD163'), NK cells (CD3- CD20- CD163) and monocytes (CD3- CD20- CD163 ${ }^{+}$). (B) Heatmaps of statistical significant changes in proteinmodification levels and total protein levels in T-lymphocytes. The analysis is based on fold change values for the modification-specific antibodies calculated from MFI measurements: MFI $I_{\text {stimulated }} / \mathrm{MFI}_{\text {control. }}$ ANOVA of the mean was used to determine statistical significant changes. (C) Unsupervised hierarchical clustering analysis of the different stimuli and signal transduction proteins in T-lymphocytes following 15 minutes of stimulation. The mean fold changes were calculated, and $\log (2)$ converted before the unsupervised hierarchical clustering analysis was performed.

\section{Alterations in p53 post-translational modifications}

Based on MFI values for total p53, p53 p-Ser15, p53 pSer37 and p53 ac-Lys382, fold change values of p53 post-translational modifications relative to total $\mathrm{p} 53$ level were calculated (Figure 5). Significant changes in phosphorylation/acetylation of p53 were seen for all leukocyte subsets. For details on time-points and pvalues, see Additional file 2: Table S2.
For T-lymphocytes, the highest khat-extract concentration reduced $\mathrm{p}$-Ser37; cathine, cathinone and the combination norephedrine/cathinone reduced $\mathrm{p}$-Ser15. For Blymphocytes, cathine, cathinone and norephedrine/ cathinone reduced p-Ser15, while cathine increased pSer37. For NK cells, the highest khat-extract concentration reduced p-Ser37 and ac-Lys382; cathine, cathinone and norephedrine/cathinone all reduced $\mathrm{p}$-Ser15. In 

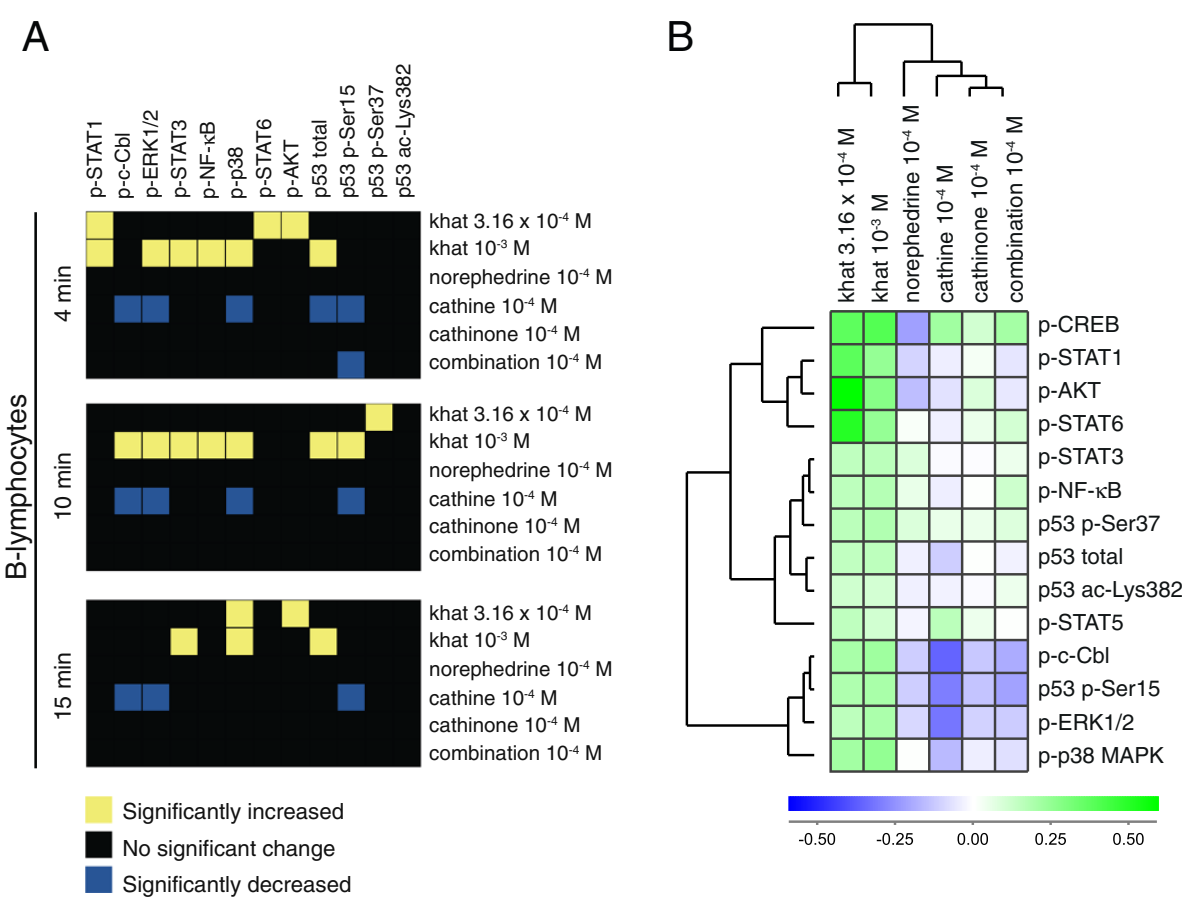

Figure 2 Signal transduction in B-lymphocytes. (A) Heatmap of statistical significant changes in protein-modification levels and total protein levels in B-lymphocytes. (B) Unsupervised hierarchical clustering analysis of the different stimuli and signal transduction proteins in B-lymphocytes following 15 minutes of stimulation.
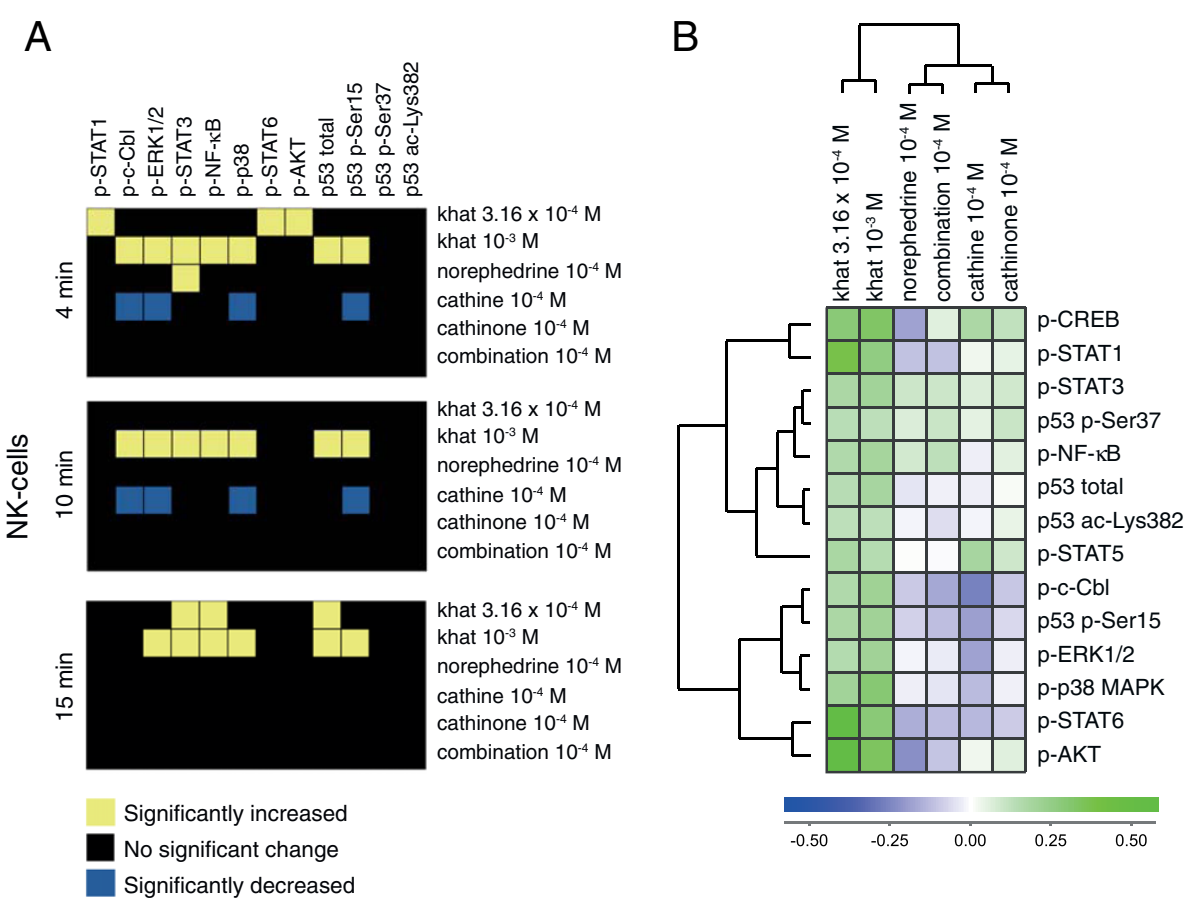

Figure 3 Signal transduction in NK cells. (A) Heatmap of statistical significant changes in protein-modification levels and total protein levels in NK-cells. (B) Unsupervised hierarchical clustering analysis of the different stimuli and signal transduction proteins in NK-cells following 15 minutes of stimulation. 

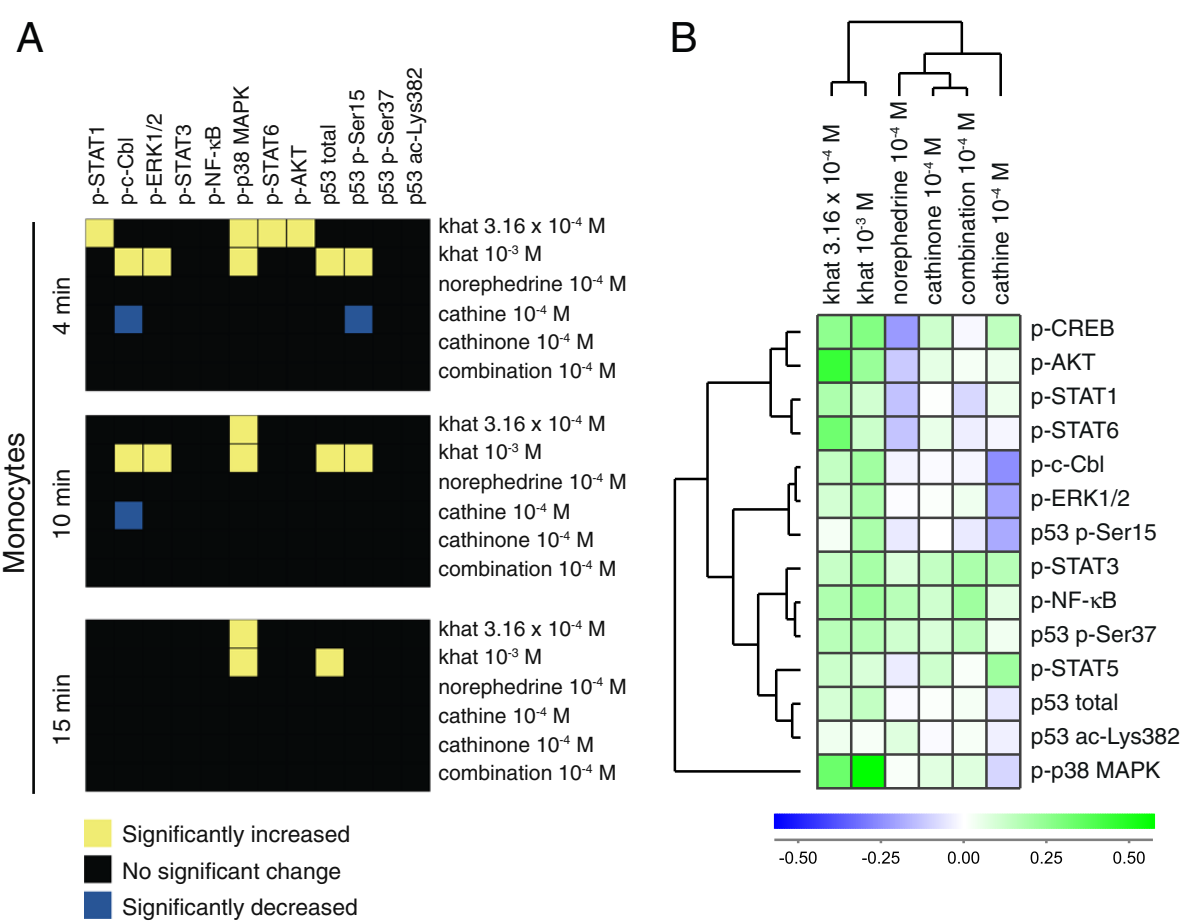

Figure 4 Signal transduction in monocytes. (A) Heatmap of statistical significant changes in protein-modification levels and total protein levels in monocytes. (B) Unsupervised hierarchical clustering analysis of the different stimuli and signal transduction proteins in monocytes following 15 minutes of stimulation.

monocytes, the highest khat-extract concentration reduced ac-Lys382; cathine reduced p-Ser15. The observations of modifications of central signal transduction pathways and stress proteins were extended with analyses of effects on cell death and proliferation in an attempt to connect early signal transduction responses with later functional effects on leukocytes.

\section{Khat, cathinone and its derivatives affected leukocyte viability and proliferation}

Levels of apoptosis were determined after 6 hours of stimulation, using Annexin V-fluorescein isothiocyanate (FITC) and propidium iodide (PI) staining followed by flow cytometric analyses (Figure 6A). The highest khatextract concentration significantly reduced the levels of viable PBMCs, whereas the lower khat-extract concentration, cathinone, cathine and norephedrine had no significant effects.

Effects on T-lymphocyte proliferation were assessed following 4 days of stimulation, based on ${ }^{3} \mathrm{H}$-thymidine incorporation (Figure 6B). The highest khat-extract concentration inhibited proliferation by approximately $50 \%$. Treatment with cathinone and cathine gave elevated CPMA values, and norephedrine significantly increased T-lymphocyte proliferation $(\mathrm{p}<0.008)$.

\section{Discussion}

Single-cell profiling of signal transduction using modificationspecific antibodies and flow cytometry represents a powerful method in analyses of signaling networks [27-29]. Here we used this method to investigate the impact on signal transduction in leukocyte subsets following short-time exposure $(4,10$ and 15 minutes) to the natural khat-derived amphetamine-like cathinone, its derivatives cathine and norephedrine, and a partly characterized khat-extract, in vitro. Functional implications were assessed based on determination of cell death induction and T-lymphocyte proliferation following long-time exposure (4 days). A summary of our present and previous findings regarding in vitro cellular effects of khat-extract is presented in Figure 7, and the present findings regarding cathinone and its natural derivatives is presented in Figure 8.

Cathinone and its natural derivatives generally suppressed basal phosphorylation of the examined signal transducers and stress sensors, while khat-extract induced protein posttranslational modifications (Figures 1, 2, 3 and 4). The different impact on signal transduction proteins in the leukocytes was reflected in the functional assays, demonstrating khat-induced cell death and reduced T-lymphocyte proliferation, whereas no cytotoxic effects were detected for cathinone, cathine and norephedrine (Figure 6). Toxic 


\section{T-lymphocytes}

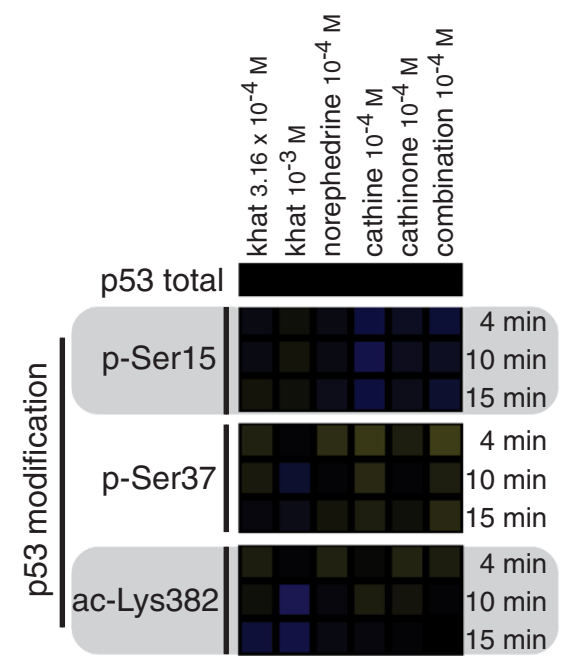

$\underline{\text { NK-cells }}$

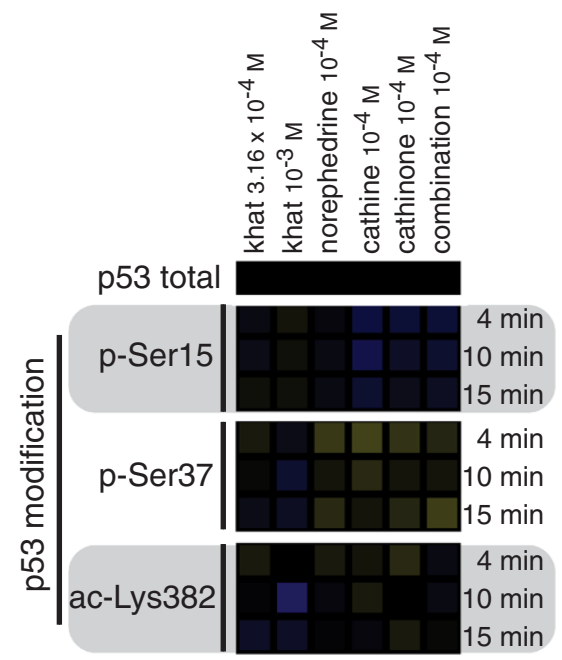

\section{B-lymphocytes}

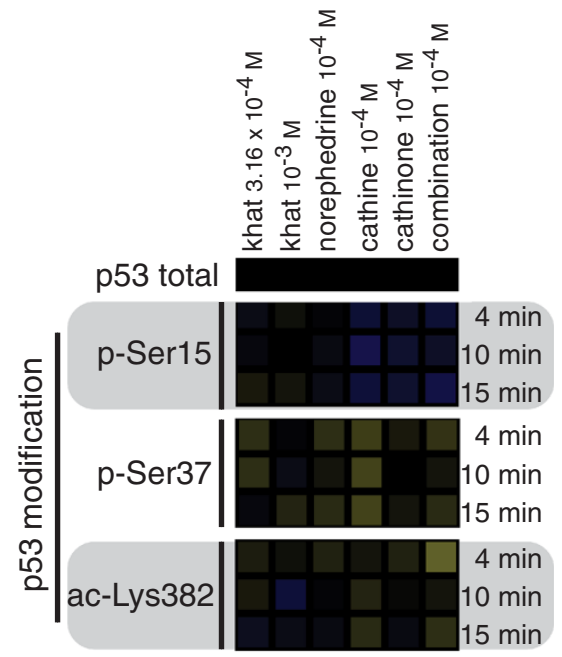

\section{Monocytes}

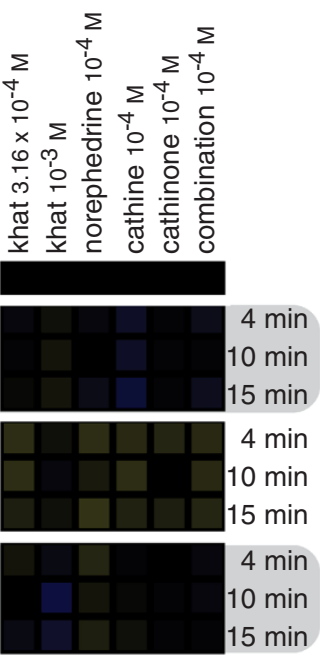

Ratio

(p53 modifications/total p53)

$0.5 \quad 1.0 \quad 1.5$

Figure 5 p53 post-translational modifications relative to total p53. Experiments and flow cytometry analyses as in the legend to Figure 1. Based on MFI values the median ratio of p-Ser15, p-Ser37 and ac-Lys382 relative to total p53 levels were determined for the various stimuli and time-points for the different leukocyte subsets.

effects by khat have been reported in in vivo and in vitro studies [3,30-32]. We have previously shown that khat induce caspase-dependent apoptosis in myeloid cells and keratinocytes [30,31,33]. Khat-induced apoptosis may involve induction of reactive oxygen species [31] (see also Aleruyani et al. for review [34]), which is described to function upstream of p53 and p38 in some model systems, while in others ROS production could be a downstream effect of p53 activation [35,36]. We therefore anticipated that single cell signalling analysis of total and modified p53 and phosphorylated p38 MAPK should reveal the mechanisms involved in khat toxicity when compared with cathinone and its natural derivatives.

There are conflicting results regarding toxic effects by cathinone and its natural derivatives [20,26,33]. Here we observed that norephedrine significantly increased T-lymphocyte proliferation after long-time exposure. A study by House and co-workers, comparing synthetic amphetamines and cathinone, demonstrated 


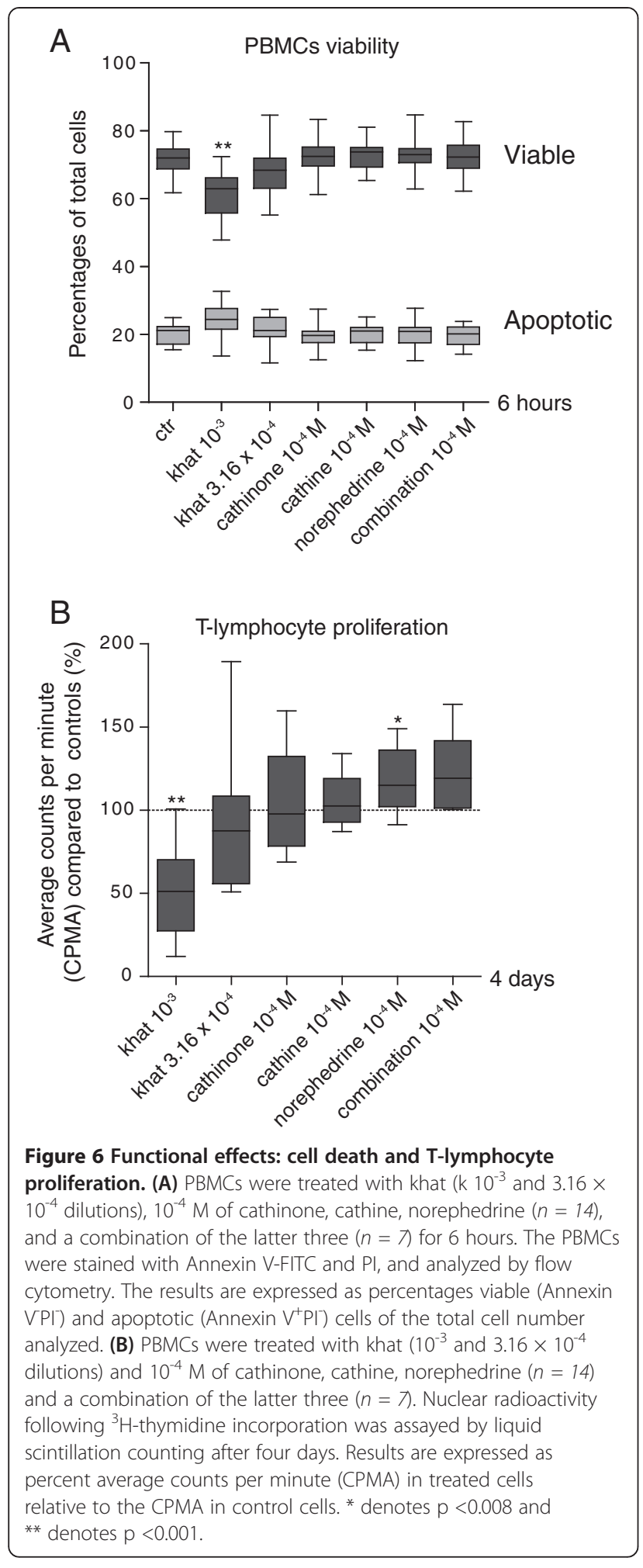

that cathinone induced B-lymphocyte proliferation, cytotoxic T-lymphocyte induction and IL-2 production [20]. As far as we know, a cell proliferative effect by norephedrine has not previously been demonstrated in vitro.
We have previously reported that khat-extract induced the tumor suppressor and cellular stress sensor p53 in normal oral keratinocytes and fibroblasts [26]. Here we demonstrate that p53 protein accumulates in leukocytes following khat-extract treatment, accompanied by, in particular, increased Ser15 phosphorylation (Figures 1, 2, 3 and 4). In contrast to khat-extract, cathinone and its derivatives generally reduced total p53 levels, p53 Ser15 phosphorylation (Figures 1, 2, 3 and 4) and Ser15 phosphorylation was further seen reduced relative to total p53 (Figure 5).

Cathine significantly reduced p38 MAPK phosphorylation in the various leukocyte subsets, whereas khat-extract mediated a significant increase in phosphorylation of this cell stress protein. In agreement with our observations, khat was recently reported to induce p38 MAPK phosphorylation in PBMCs in vitro, and khat-treatment was seen to induce cell death by apoptosis [32]. p38 is probably acting upstream of p53, and may be pivotal in khat-induced abnormal differentiation of in vitro-reconstructed human normal buccal mucosa [37]. Additionally, our data indicate that in particular cathine attenuated c$\mathrm{Cbl}$, ERK1/2 and p53 Ser15 phosphorylation in the various subsets, further including p-STAT6 and p-Akt reduction in T-lymphocytes (Figure 1). Interestingly, c-Cbl was recently reported to play an important role in trafficking of the $5-\mathrm{HT}_{2 \mathrm{~A}}$ receptor in human embryonic kidney cells [38], whereas de-phosphorylation of AKT was observed following stimulation of striatal class D2 dopamine receptors [39,40].

Our results suggest that cathinone and its derivatives generally reduced basal phosphorylation levels of the proteins analysed, but as an exception, norephedrine was seen to significantly induce phosphorylation of STAT3 in NK cells. STAT3 is known to induce both proliferative and anti-proliferative effects, but a recent study suggested that STAT3 could mediate an immunosuppressive effect in NK cells [41]. Further, even if not statistical significant, cathine and cathinone indicated elevated p-CREB levels in all leukocyte subsets, whereas norephedrine reduced basal phosphorylation of CREB. Our results may indicate that the alkaloids cathine and cathinone induce CREB phosphorylation as has been shown for e.g. ephedrine. Ephedrine, an alkaloid chemically similar to cathinone, has been suggested to induce PKA-mediated CREB phosphorylation through $\beta$-adrenergic receptor/cyclic AMP/PKA/DARPP-32 signaling pathway [42]. Taken together these observations show that cathinone, cathine and norephedrine resulted in distinct signaling signatures, even if the compounds are closely related structurally. 


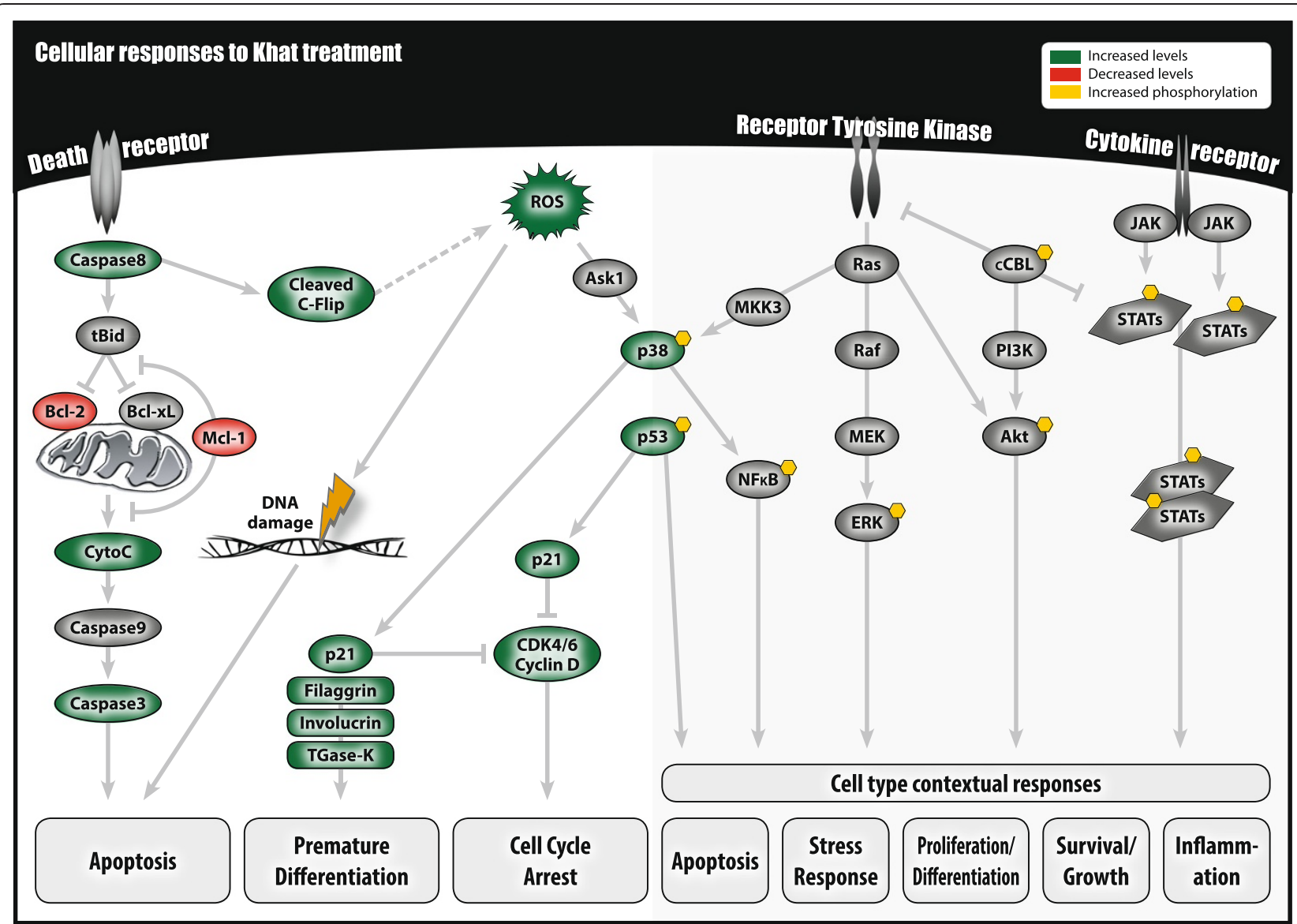

Figure 7 A summary of previous and present findings of cellular effects of khat-extract. Our studies have shown that exposure of various cell types (i.e. leukemic cell lines, normal oral keratinocytes and fibroblasts, normal peripheral leukocytes) to khat-extract in vitro affects various proteins involved in cell death, cell stress, cell cycle regulation, differentiation and cell signaling $[26,30,31,33,37]$.

The leukocyte subsets differed in their signaling responses to the various treatments, and B-lymphocytes and NK cells were generally seen as more responsive compared to T-lymphocytes and monocytes. This observation could relate to varying levels or different repertoires of monoamine transporters and receptors on the immune cells. For instance, T-lymphocytes and monocytes were reported to exhibit a low expression of dopamine receptors when compared to B-lymphocytes and NK cells, which displayed a higher and more consistent expression [43]. The mechanism(s) behind the different responses to khat-extract, cathinone and its derivatives seen in the various leukocyte subsets should be addressed in future studies.

In recent years, synthetic cathinone derivatives have been designed, being widely distributed as recreational drugs. The use of these drugs has been reported with harmful health effects, and has been suspected to be involved in several deaths [44]. Signal transduction studies and functional assays of synthetic cathinone derivatives and other amphetamine-like agents, like the ones performed here, could be useful in evaluation of potential harmful short term and long term effects on various immune cells. In this study we observed significant changes in phosphorylation levels for several of the investigated signal transduction and cell stress proteins, but the changes were still modest. In order to evaluate more fully the impact of pharmacological substrates on cells of the immune system, the approach should be extended and involve analyses of immune cells following in vivo studies with experimental animals.

\section{Conclusions}

We report that the khat-derived cathinone and its derivatives generally reduced the levels of activating protein modifications of signal transducers and stress sensors in leukocytes, and that norephedrine increased in vitro T-lymphocyte proliferation. The closely structurally related compounds cathinone, cathine and norephedrine were seen to induce unique signaling signatures in leukocytes. Further, this study 


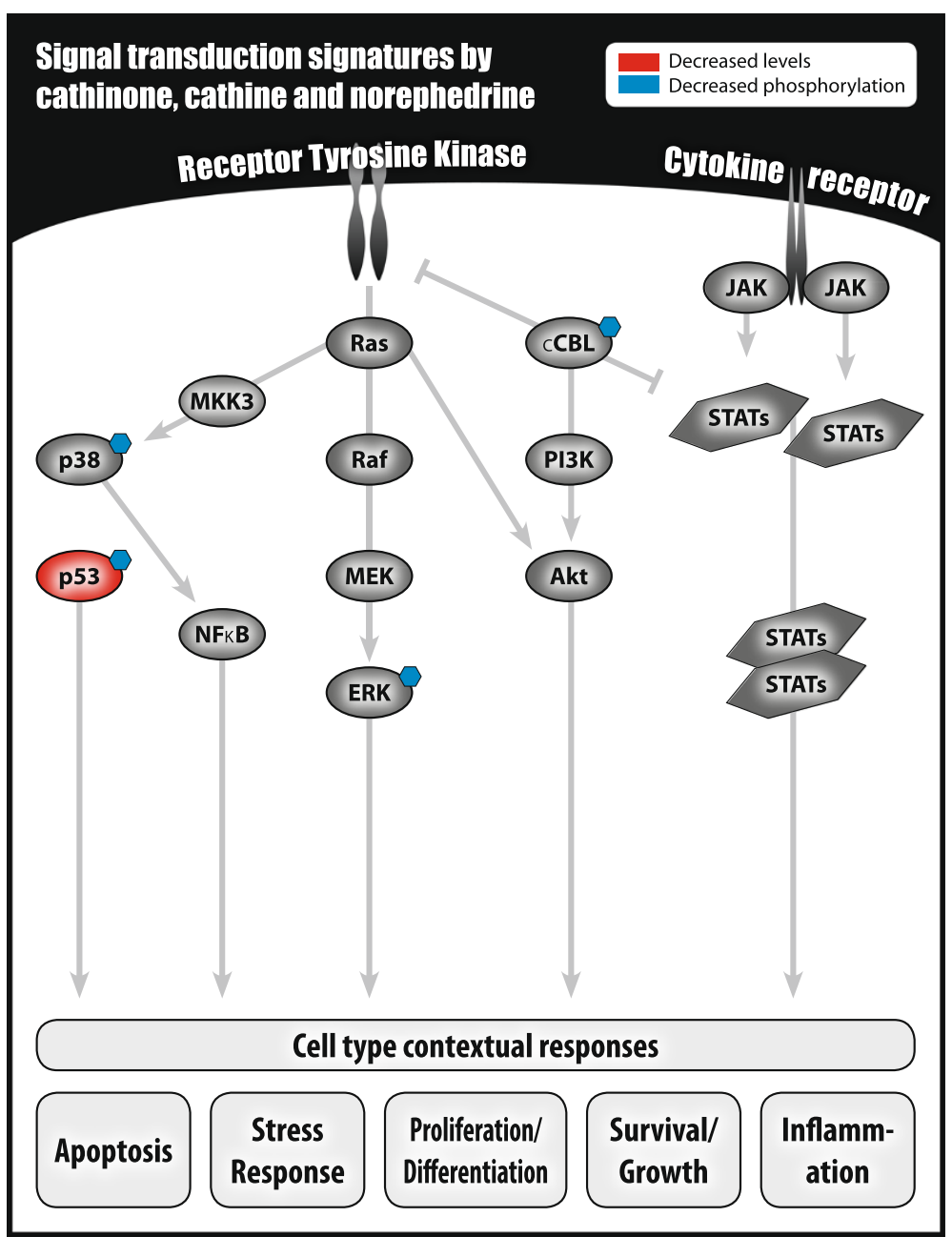

Figure $8 \mathrm{~A}$ summary of our present findings of cell signal transduction signatures in leukocytes stimulated with amphetamine-like cathinone, cathine or norephedrine.

confirmed that compounds in a botanical khat-extract activated cell stress sensors in immune cells and induced cytotoxic effects. Our results suggest that single-cell flow cytometric analysis of intracellular signaling pathways may be an informative and feasible approach when elucidating pharmacological effects and mechanisms of action in immune cells.

\section{Methods}

\section{Blood donors}

Blood was obtained from healthy donors from Department of Immunology and Transfusion Medicine, Haukeland University Hospital, Bergen, Norway. The blood donors used in the signal transduction analyses were 6 healthy individuals (4 females, 2 males) with a mean age of 38.2 years (range: 24-59). The use of blood for research purposes was approved by the local ethics committee REK (Regionale komiteer for medisinsk og helsefaglig forskningsettikk), Haukeland University Hospital, and samples collected after written consent by the blood donors, in accordance with the Declaration of Helsinki.

\section{Cathinone, cathine and norephedrine}

S-(-)-cathinone, (1S,2S)-(+)-norpseudoephedrine (cathine) and (1R,2S)-(-)-norephedrine were purchased from Sigma-Aldrich, and dissolved in DMSO (Sigma-Aldrich). These compounds were used in cell cultures at the concentration $10^{-4} \mathrm{M}$, and import and experiments were performed after written permission from The Norwegian Medicines Agency.

\section{Khat-extract}

Khat (asili cultivate) from the Meru district in Kenya was purchased in Nairobi, transported at $4^{\circ} \mathrm{C}$ under moist conditions, and the material was extracted within $48 \mathrm{hrs}$ of harvest with methanol [30,33]. The khatextract was prepared from approximately $200 \mathrm{~g}$ of khat, using the leaves and the soft parts of the twigs, which 
were chopped into pieces of approximately $5 \mathrm{~mm}$ length and submerged in methanol. The methanol extract was dried using a rotary evaporator, the semi-solid residue dissolved at a concentration of $0.2 \mathrm{~g} / \mathrm{ml}$ in dimethylsulphoxide (DMSO; Sigma, St. Louis, MO, USA) and the stock solution stored at $-80^{\circ} \mathrm{C}$.

The stock solution was diluted in Roswell Park Memorial Institute (RPMI)-1640 medium (Sigma-Aldrich) with $10 \%$ fetal bovine serum (FBS), $2 \mathrm{mM}$ L-glutamine and antibiotics (100 $\mathrm{IU} \mathrm{ml}^{-1}$ penicillin and $100 \mu \mathrm{g} \mathrm{m}{ }^{-1}$ streptomycin; Gibco, Grand Island, NY, USA), and precipitates removed by centrifugation (10 000 g, 15 minutes, $4^{\circ} \mathrm{C}$ ) [30]. The khat-extract supernatant was added experimental cell cultures giving final dilutions of $10^{-3}$ and $3.16 \times 10^{-4}$, based on previous studies [30]. All experimental cell cultures contained $0.1 \%$ DMSO.

Cathinone is relatively unstable, being transformed to cathine upon wilting of khat leaves, while being metabolized predominantly to norephedrine in vivo $[3,4]$. Cathinone, cathine and norephedrine are therefore suited as reference substances, indicating the freshness of the khat sample and the stability of the khat-extract. The concentrations of cathinone, cathine and norephedrine in the khat-extract were determined using high pressure liquid chromatography and mass spectrometry (HPLC-MS-MS), as previously described [30], and the values are displayed in Table 1, together with experimental cell culture concentrations.
In order to import and study khat, classified as an illegal narcotic substance in Norway, written permission was obtained from The Norwegian Medicines Agency (permission 01/705 of 2002-07-08).

\section{Peripheral blood mononuclear cells}

Peripheral blood mononuclear cells (PBMCs) were isolated from buffy coats using density gradient separation (Lymphoprep; Nycomed, Oslo, Norway; specific density 1.077), and resuspended at: (i) $1 \times 10^{6}$ cells ml $^{-1}$ in $\mathrm{X}$ vivo10 $^{\circ}$ culture medium (BioWhittaker, Walkersville, MA, USA) with $100 \mu \mathrm{g} \mathrm{ml}^{-1}$ gentamicin for use in proliferation studies, (ii) $1 \times 10^{6}$ cells $\mathrm{ml}^{-1}$ in RPMI-1640 medium (10\% FBS, L-glutamine, antibiotics) for studies on signal transduction, or (iii) 200000 cells $\mathrm{ml}^{-1}$ in RPMI-1640 medium (10\% FBS, L-glutamine, antibiotics) when determining apoptosis.

\section{Annexin V-fluorescein isothiocyanate (FITC)/propidium iodide $(\mathrm{PI})$ staining}

When determining apoptosis, the PBMCs were stained with Annexin V-FITC and PI, using the Apoptest ${ }^{\mathrm{TM}}$ kit from Nexins Research (Hoeven, the Netherlands) according to the manufacturer's protocol. Data were collected on a FACS Calibur flow cytometer (Becton Dickinson, BD, Immunocytometry Systems, San Jose, CA, USA) and analyzed with FlowJo 7.2.5 software (TreeStar Inc., Ashland, OR, USA).

Table 2 Antibodies used in this study

\begin{tabular}{|c|c|c|c|c|}
\hline Antigen & Epitope & Clone & Conjugate & Manufacturer \\
\hline$\overline{\mathrm{AKT}}$ & $\mathrm{p}-$ Ser473 & F29-763 & Alexa Fluor ${ }^{\circledR} 647$ & $\mathrm{BD}$ \\
\hline CREB & p-Ser133 & J151-21 & Alexa Fluor ${ }^{\circledR} 647$ & $\mathrm{BD}$ \\
\hline p38 & p-Thr180/p-Tyr182 & 36/p38 & Alexa Fluor ${ }^{\circledR} 488$ & $\mathrm{BD}$ \\
\hline $\mathrm{ERK} 1 / 2$ & p-Thr202/p-Tyr204 & $20 A$ & Alexa Fluor ${ }^{\circledast} 488$ & $\mathrm{BD}$ \\
\hline STAT1 & p-Tyr701 & $4 a$ & Alexa Fluor ${ }^{\circledast} 647$ & $\mathrm{BD}$ \\
\hline STAT3 & p-Tyr705 & 4/P-STAT3 & Alexa Fluor ${ }^{\oplus} 488$ & $\mathrm{BD}$ \\
\hline STAT5 & p-Tyr694 & 47 & Alexa Fluor ${ }^{\circledR} 647$ & $\mathrm{BD}$ \\
\hline STAT6 & p-Tyr641 & 18/P-STAT6 & Alexa Fluor ${ }^{\circledast} 647$ & $\mathrm{BD}$ \\
\hline p53 & aa $1-45$ & DO-7 & FITC & $\mathrm{BD}$ \\
\hline p53 & $\mathrm{p}-\operatorname{Ser} 37$ & J159-641.79 & Alexa Fluor ${ }^{\circledast} 647$ & $\mathrm{BD}$ \\
\hline p53 & $\mathrm{p}-\operatorname{Ser} 15$ & $16 \mathrm{G} 8$ & Alexa Fluor ${ }^{\circledast} 488$ & Cell Signaling Technologies \\
\hline p53 & ac-Lys382 & L82-51 & Alexa Fluor ${ }^{\circledR} 647$ & $\mathrm{BD}$ \\
\hline$N F-K B$ & p-Ser529 & K10-895.12.50 & Alexa Fluor ${ }^{\circledR} 488$ & $\mathrm{BD}$ \\
\hline$c-C b l$ & p-Tyr700 & $47 / c-C b \mid$ & Alexa Fluor ${ }^{\circledR} 488$ & $\mathrm{BD}$ \\
\hline CD3 & CD3 & SK7 & PE-Cy7 & $\mathrm{BD}$ \\
\hline CD20 & CD20 & $\mathrm{H} 1(\mathrm{FB} 1)$ & PerCP-Cy 5.5 & $\mathrm{BD}$ \\
\hline CD163 & CD163 & Mac2-158 & PE & Trillium Diagnostics \\
\hline
\end{tabular}




\section{${ }^{3} \mathrm{H}$-thymidine proliferation assay}

The assay used to determine in vitro lymphocyte proliferation is based on a whole blood protocol [45]. Experiments were performed in triplicates in 96-well plates, and each well added (i) $5 \times 10^{4}$ PBMCs; (ii) CD3 antibody (mouse IgE Moab; CLB-T3/4.E), final concentration $316 \mathrm{ng} \mathrm{ml}^{-1}$; (iii) CD28 antibody (mouse IgG1 Moab, CLB-CD28/1), final concentration 842 $\mathrm{ng} \mathrm{ml}{ }^{-1}$; and (iv) test compound (cathinone, cathine, norephedrine, khat-extract) or control medium. The cell cultures were incubated $\left(37^{\circ} \mathrm{C}, 5 \% \mathrm{CO}_{2}\right)$ for 3 days, added ${ }^{3} \mathrm{H}$-thymidine $(37 \mathrm{kBq}$ per well; TRA 310, Amersham International, Amersham, UK), and nuclear radioactivity assayed on day four by liquid scintillation counting. Results are expressed as percent average counts per minute (CPMA) in treated cells relative to CPMA in controls: $\left(\mathrm{CPMA}_{\text {treated }} /\right.$ $\left.\mathrm{CPMA}_{\text {control }}\right) \times 100$. All CPMA values were $>1000$, indicating proliferating cells.

\section{Intracellular staining of proteins and flow cytometric analyses}

PBMCs were fixed in $1.6 \%$ paraformaldehyde, permeabilized with $100 \%$ methanol and stored at $-80^{\circ} \mathrm{C}$ until flow cytometric analysis. To achieve high-throughput and to reduce costs, the PBMCs were barcoded [29], and intracellular proteins stained as previously described [46]. Data were collected on a FACS Fortessa (BD) and analyzed with Stanford CytoBank software (http:// cytobank.stanford.edu/public/openid/). Median fluorescence intensity (MFI) values were used as basis for data analyses. Antibodies used are listed in Table 2.

\section{Statistical and bioinformatical approaches}

Heatmaps: Statistical comparisons were made using GraphPad PRISM (version 5.0, GraphPad Software, Inc., USA) software, with one-way analysis of variance (ANOVA) and Tukey's multiple comparison post-tests to determine significant differences. A Student's unpaired or paired t-test was employed when only two groups were compared. Cluster analyses: Analysis were performed using J-Express 2011 analysis suite (MolMine AS, Bergen, Norway) [47]. For each protein the mean fold change for the donors was calculated, for each leukocyte subset and each time point. Values were $\log (2)$ converted before unsupervised hierarchical clustering analyses were performed using Euclidean correlation with complete linkage.

\section{Additional files}

Additional file 1: Table S1. Levels of significance for the observed in vitro induced phosphorylation/acetylation alterations of all target molecules.
Additional file 2: Table S2. Levels of significance for the observed in vitro induced phosphorylation/acetylation alterations of p53.

\section{Competing interests}

The authors declare that they have no competing interests.

\section{Authors' contributions}

TB and EE conceived, designed and performed experiments, analyzed data and wrote the manuscript. BSE participated during experiments and performed statistical analyses. AS participated during experiments and performed flow cytometric analyses. HR performed statistical analyses. HJA, $\mathrm{ACJ}, \mathrm{OKV}$ and $\varnothing \mathrm{B}$ conceived and guided the study. BTG conceived and guided the study, and wrote the manuscript. All authors read and approved the final manuscript.

\section{Acknowledgements}

This work was supported by funding from the following grants: The Norwegian Cancer Society with Solveig and Ole Lunds Legacy, the Western Regional Norwegian Authority (Helse-Vest), and the Norwegian Research Council with Programme in Functional Genomics. The authors would like to thank Kåre Strønen for his valuable contribution to improve the figures.

\section{Author details}

'Department of Clinical Science, University of Bergen, Bergen, Norway. ${ }^{2}$ Institute of Biomedical Laboratory Sciences, Bergen University College, Bergen, Norway. ${ }^{3}$ Department of Internal Medicine, Haukeland University Hospital, Bergen, Norway. ${ }^{4}$ Department of Head and Neck Surgery, Haukeland University Hospital, Bergen, Norway. ${ }^{5}$ Department of Clinical Medicine, University of Bergen, Bergen, Norway. ${ }^{6}$ Department of Pathology, Haukeland University Hospital, Bergen, Norway.

Received: 1 March 2013 Accepted: 3 July 2013

Published: 11 July 2013

\section{References}

1. Al-Hebshi NN, Skaug N: Khat (Catha edulis)-an updated review. Addict Biol 2005, 10(4):299-307.

2. Al-Motarreb A, Baker K, Broadley KJ: Khat: pharmacological and medical aspects and its social use in Yemen. Phytother Res 2002, 16(5):403-413.

3. Kalix P: Pharmacological properties of the stimulant khat. Pharmacol Ther 1990, 48(3):397-416.

4. Toennes SW, Kauert GF: Excretion and detection of cathinone, cathine, and phenylpropanolamine in urine after kath chewing. Clin Chem 2002, 48(10):1715-1719.

5. Brenneisen R, Geisshulser S, Schorno X: Merucathine, A New Phenylalkylamine from Catha edulis. Planta Med 1984, 50(6):531.

6. Crombie L: The cathedulin alkaloids. Bull Narc 1980, 32(3):37-50.

7. Halbach $\mathrm{H}$ : Medical aspects of the chewing of khat leaves. Bull World Health Organ 1972, 47(1):21-29.

8. Toennes SW, Harder S, Schramm M, Niess C, Kauert GF: Pharmacokinetics of cathinone, cathine and norephedrine after the chewing of khat leaves. Br J Clin Pharmacol 2003, 56(1):125-130.

9. Cleary L, Docherty JR: Actions of amphetamine derivatives and cathinone at the noradrenaline transporter. Eur J Pharmacol 2003, 476(1-2):31-34.

10. Rothman RB, Vu N, Partilla JS, Roth BL, Hufeisen SJ, Compton-Toth BA, Birkes J, Young R, Glennon RA: In vitro characterization of ephedrine-related stereoisomers at biogenic amine transporters and the receptorome reveals selective actions as norepinephrine transporter substrates. J Pharmacol Exp Ther 2003, 307(1):138-145.

11. Glennon RA, Liebowitz SM: Serotonin receptor affinity of cathinone and related analogues. J Med Chem 1982, 25(4):393-397.

12. Hassan NA, Gunaid AA, El-Khally FM, Al-Noami MY, Murray-Lyon IM: Khat chewing and arterial blood pressure. A randomized controlled clinical trial of alpha-1 and selective beta-1 adrenoceptor blockade. Saudi Med J 2005, 26(4):537-541.

13. Nasher AA, Qirbi AA, Ghafoor MA, Catterall A, Thompson A, Ramsay JW, Murray-Lyon IM: Khat chewing and bladder neck dysfunction. A randomized controlled trial of alpha 1-adrenergic blockade. $\mathrm{Br} J$ Urol 1995, 75(5):597-598. 
14. Gordon J, Barnes NM: Lymphocytes transport serotonin and dopamine: agony or ecstasy? Trends Immunol 2003, 24(8):438-443.

15. Meredith EJ, Chamba A, Holder MJ, Barnes NM, Gordon J: Close encounters of the monoamine kind: immune cells betray their nervous disposition. Immunology 2005, 115(3):289-295.

16. Josefsson E, Bergquist J, Ekman R, Tarkowski A: Catecholamines are synthesized by mouse lymphocytes and regulate function of these cells by induction of apoptosis. Immunology 1996, 88(1):140-146.

17. Bergquist J, Silberring J: Identification of catecholamines in the immune system by electrospray ionization mass spectrometry. Rapid Commun Mass Spectrom 1998, 12(11):683-688.

18. Mata S, Urbina M, Manzano E, Ortiz T, Lima L: Noradrenaline transporter and its turnover rate are decreased in blood lymphocytes of patients with major depression. J Neuroimmunol 2005, 170(1-2):134-140.

19. Boyle NT, Connor TJ: Methylenedioxymethamphetamine ('Ecstasy')induced immunosuppression: a cause for concern? Br J Pharmacol 2010, 161(1):17-32.

20. House RV, Thomas PT, Bhargava HN: Comparison of immune functional parameters following in vitro exposure to natural and synthetic amphetamines. Immunopharmacol Immunotoxicol 1994, 16(1):1-21.

21. Freire-Garabal M, Nunez MJ, Balboa JL, Fernandez-Rial JC, Belmonte A: Effects of amphetamine on the activity of phagocytosis in mice. Life Sci 1992, 51(15):PL145-PL148.

22. McAlees JW, Sanders VM: Hematopoietic protein tyrosine phosphatase mediates beta2-adrenergic receptor-induced regulation of p38 mitogen-activated protein kinase in B lymphocytes. Mol Cell Biol 2009, 29(3):675-686

23. Lajevic MD, Suleiman S, Cohen RL, Chambers DA: Activation of p38 mitogen-activated protein kinase by norepinephrine in T-lineage cells. Immunology 2011, 132(2):197-208.

24. Leon-Ponte M, Ahern GP, O'Connell PJ: Serotonin provides an accessory signal to enhance T-cell activation by signaling through the 5-HT7 receptor. Blood 2007, 109(8):3139-3146.

25. Huang Y, Qiu AW, Peng YP, Liu Y, Huang HW, Qiu YH: Roles of dopamine receptor subtypes in mediating modulation of $\mathrm{T}$ lymphocyte function. Neuro Endocrinol Lett 2010, 31(6):782-791.

26. Lukandu OM, Costea DE, Dimba EA, Neppelberg E, Bredholt T, Gjertsen BT, Vintermyr OK, Johannessen AC: Khat induces G1-phase arrest and increased expression of stress-sensitive p53 and p16 proteins in normal human oral keratinocytes and fibroblasts. Eur J Oral Sci 2008 116(1):23-30.

27. Sachs K, Perez O, Pe'er D, Lauffenburger DA, Nolan GP: Causal protein-signaling networks derived from multiparameter single-cell data. Science 2005, 308(5721):523-529.

28. Krutzik PO, Crane JM, Clutter MR, Nolan GP: High-content single-cell drug screening with phosphospecific flow cytometry. Nat Chem Biol 2008, 4(2):132-142.

29. Krutzik PO, Nolan GP: Fluorescent cell barcoding in flow cytometry allows high-throughput drug screening and signaling profiling. Nat Methods 2006, 3(5):361-368

30. Bredholt T, Dimba EA, Hagland HR, Wergeland L, Skavland J, Fossan KO, Tronstad KJ, Johannessen AC, Vintermyr OK, Gjertsen BT: Camptothecin and khat (Catha edulis Forsk.) induced distinct cell death phenotypes involving modulation of c-FLIPL, Mcl-1, procaspase- 8 and mitochondrial function in acute myeloid leukemia cell lines. Mol Cancer 2009, 8:101.

31. Lukandu OM, Costea DE, Neppelberg E, Johannessen AC, Vintermyr OK: Khat (Catha edulis) induces reactive oxygen species and apoptosis in normal human oral keratinocytes and fibroblasts. Toxicol Sci 2008, 103 (2):311-324

32. Murdoch C, Aziz HA, Fang HY, Jezan H, Musaid R, Muthana M: Khat (Catha edulis) alters the phenotype and anti-microbial activity of peripheral blood mononuclear cells. J Ethnopharmacol 2011, 138(3):780-787.

33. Dimba EA, Gjertsen BT, Bredholt T, Fossan KO, Costea DE, Francis GW, Johannessen AC, Vintermyr OK: Khat (Catha edulis)-induced apoptosis is inhibited by antagonists of caspase- 1 and -8 in human leukaemia cells. Br J Cancer 2004, 91(9):1726-1734.

34. Aleryani SL, Aleryani RA, Al-Akwa AA: Khat a drug of abuse: roles of free radicals and antioxidants. Drug Test Anal 2011, 3(9):548-551.

35. Maillet A, Pervaiz S: Redox regulation of $p 53$, redox effectors regulated by p53: a subtle balance. Antioxid Redox Signal 2012, 16(11):1285-1294
36. Matsuzawa A, Ichijo $H$ : Redox control of cell fate by MAP kinase: physiological roles of ASK1-MAP kinase pathway in stress signaling. Biochim Biophys Acta 2008, 1780(11):1325-1336.

37. Lukandu OM, Neppelberg E, Vintermyr OK, Johannessen AC, Costea DE: Khat alters the phenotype of in vitro-reconstructed human oral mucosa. J Dent Res 2010, 89(3):270-275.

38. Baldys A, Raymond JR: Role of c-Cbl carboxyl terminus in serotonin 5-HT2A receptor recycling and resensitization. J Biol Chem 2011, 286(28):24656-24665.

39. Beaulieu JM, Sotnikova TD, Marion S, Lefkowitz RJ, Gainetdinov RR, Caron MG: An Akt/beta-arrestin 2/PP2A signaling complex mediates dopaminergic neurotransmission and behavior. Cell 2005, 122(2):261-273.

40. Beaulieu JM, Sotnikova TD, Yao WD, Kockeritz L, Woodgett JR, Gainetdinov RR, Caron MG: Lithium antagonizes dopamine-dependent behaviors mediated by an AKT/glycogen synthase kinase 3 signaling cascade. Proc Natl Acad Sci U S A 2004, 101(14):5099-5104.

41. Bedel R, Thiery-Vuillemin A, Grandclement C, Balland J, Remy-Martin JP, Kantelip B, Pallandre JR, Pivot X, Ferrand C, Tiberghien P, et al: Novel role for STAT3 in transcriptional regulation of NK immune cell targeting receptor MICA on cancer cells. Cancer Res 2011, 71(5):1615-1626.

42. Jia JJ, Zeng XS, Li Y, Ma S, Bai J: Ephedrine induced thioredoxin-1 expression through beta-adrenergic receptor/cyclic AMP/protein kinase A/dopamine- and cyclic AMP-regulated phosphoprotein signaling pathway. Cell Signal 2013, 25(5):1194-1201.

43. McKenna F, McLaughlin PJ, Lewis BJ, Sibbring GC, Cummerson JA, Bowen-Jones D, Moots RJ: Dopamine receptor expression on human T- and B-lymphocytes, monocytes, neutrophils, eosinophils and NK cells: a flow cytometric study. J Neuroimmunol 2002, 132(1-2):34-40.

44. Morris K: UK places generic ban on mephedrone drug family. Lancet 2010, 375(9723):1333-1334

45. Wendelbo O, Bruserud O: Functional evaluation of proliferative T cell responses in patients with severe $T$ lymphopenia: characterization of optimal culture conditions and standardized activation signals for a simple whole blood assay. J Hematother Stem Cell Res 2003, 12(5):525-535.

46. Irish JM, Anensen N, Hovland R, Skavland J, Borresen-Dale AL, Bruserud O, Nolan GP, Gjertsen BT: Flt3 Y591 duplication and Bcl-2 overexpression are detected in acute myeloid leukemia cells with high levels of phosphorylated wild-type p53. Blood 2007, 109(6):2589-2596.

47. Stavrum AK, Petersen K, Jonassen I, Dysvik B: Analysis of gene-expression data using J-Express. Curr Protoc Bioinformatics 2008: . Chapter 7:Unit 73.

doi:10.1186/2050-6511-14-35

Cite this article as: Bredholt et al:: Distinct single cell signal transduction signatures in leukocyte subsets stimulated with khat extract, amphetamine-like cathinone, cathine or norephedrine. BMC Pharmacology and Toxicology 2013 14:35.

\section{Submit your next manuscript to BioMed Central and take full advantage of:}

- Convenient online submission

- Thorough peer review

- No space constraints or color figure charges

- Immediate publication on acceptance

- Inclusion in PubMed, CAS, Scopus and Google Scholar

- Research which is freely available for redistribution 